\title{
Configurações
}

Revista Ciências Sociais

\section{Desigualidades de género}

Gender inequalities: blank for a protheoretical map

Inégalités de genre: esquisse pour un plan prothéorique

\section{Manuel Carlos Silva}

\section{(2) OpenEdition \\ Journals}

Edição electrónica

URL: https://journals.openedition.org/configuracoes/370

DOI: $10.4000 /$ configuracoes.370

ISSN: 2182-7419

\section{Editora}

Centro de Investigação em Ciências Sociais

\section{Edição impressa}

Data de publição: 1 janeiro 2008

Paginação: 65-89

ISSN: 1646-5075

\section{Refêrencia eletrónica}

Manuel Carlos Silva, «Desigualidades de género», Configurações [Online], 4 | 2008, posto online no dia 12 fevereiro 2012, consultado o 21 setembro 2021. URL: http://journals.openedition.org/ configuracoes/370 ; DOI: https://doi.org/10.4000/configuracoes.370

Este documento foi criado de forma automática no dia 21 setembro 2021. 


\title{
Desigualidades de género
}

\author{
Gender inequalities: blank for a protheoretical map \\ Inégalités de genre: esquisse pour un plan prothéorique
}

\author{
Manuel Carlos Silva
}

\section{Introdução: problema e perspectivas teóricas}

1 Ainda que sob diversas formas e graus, as desigualdades de género têm constituído um fenómeno histórico recorrente em diversos tipos de sociedade. Na moderna sociedade capitalista, elas têm-se imbricado nos processos de (re)produção desta e nalguns dos seus mecanismos políticos e ideológicos, ocultando-se, aliás não raro, sob razões "naturais", "biológicas" ou "(pseudo)psicológicas" (cf. Hartman 1982; Weeks

1986; Liljestrom 1986; Amâncio 1994; Bourdieu 1998; Crompton 2003). Embora o grau de constrangimento ${ }^{1}$ para explicar as desigualdades de género se mantenha uma questão polémica, as desigualdades de género manifestam disparidade no acesso e no controlo de recursos, designadamente oportunidades e remunerações e demais condições sociais (cf. González et al. 1992: 199 ss), tanto na vida pública, como na vida familiar/privada (cf. Abbot e Wallace 1991).

3 Tal como outras sociedades democráticas, Portugal conheceu uma redução das desigualdades de género, sobretudo graças à acção dos movimentos sociais feministas e dalgumas forças políticas. Não obstante as consideráveis alterações nas últimas décadas no sentido do tratamento político-jurídico-legal igualitário de homens e mulheres e de se verificar uma notável diminuição de desigualdades de género, estas, quer vistas numa perspectiva diacrónica, quer consideradas numa abordagem sincrónica, são ainda uma realidade actual e operante a vários níveis. Recentes estudos evidenciam que as fronteiras e desigualdades de género ainda persistem em várias vertentes e sectores da vida social: nos preconceitos e nas avaliações negativas das mulheres nos contextos institucionais e nas interacções quotidianas; nos sistemas de herança e casamento (O'Neill 1984; Iturra 1983; Geraldes 1986; Silva 1998; Sobral 1999), assim como nos processos de separação ou divórcio e subsequente tutela e guarda dos filhos ${ }^{2}$ (Torres 2001), nas concepções sobre o 
masculino e o feminino (Amâncio 1993, 1994), bem como nos códigos em torno da honravergonha (Cutileiro 1977, 1988; Silva 2002); na desigual distribuição do poder doméstico (Silva 1991) e na violência doméstica (Dias 1998); nos modos de residência e na divisão sexual do trabalho e na sobrecarga das tarefas domésticas (Wall 1998); na segmentação sexual dos mercados de trabalho e nas oportunidades de emprego e nas remunerações (Ferreira 1993; Marques 2002); na desvalorização dos percursos profissionais das mulheres e sua baixa participação nas lideranças e na vida política (Viegas e Faria 1999).

Em termos mais globais e históricos, a questão que se coloca poder-se-ia enunciar do seguinte modo: como compreender e explicar o recorrente fenómeno histórico da dominação masculina em sociedades e Estados basicamente patriarcais, quer esclavagistas e despóticos, quer feudais-aristocráticos e capitalistas, quer ainda em sociedades ditas socialistas ou que tentaram caminhar na construção do socialismo? No âmbito mais circunscrito deste texto, quais os factores estruturantes da reemergência e reprodução das desigualdades de género nos dias de hoje?

Diversas têm sido as abordagens sociopolíticas perante este problema social tornado também um problema sociológico, sobre o qual, como veremos de seguida, têm incidido diversos olhares teórico-metodológicos.

\section{Algumas perspectivas teóricas}

6 Uma das concepções correntes da discriminação sexual assentaria numa visão sociobiológica, a qual tende a veicular a ideia preconcebida de que, enquanto o homem seria um ser mais activo e agressivo, mais predisposto ao combate público e ao sucesso, a mulher deteria uma construção biológica mais passiva e orientada para a procriação e o cuidado da casa. Uma tal posição ideológica patriarcal e social-darwinista pretende, em última instância, justificar o tradicional domínio do mais forte social e politicamente: o homem. Se é inegável que certos traços físicos e fenotípicos específicos acompanham de modo indelével respectivamente homens e mulheres, eles têm dado todavia lugar a representações e categorizações que não têm fundamento, a não ser como modos de legitimação e dominação masculinas. Ou seja, a partir do diferente fenótipo sexual - que não pode ser negado ou subavaliado -, acentuam-se de modo subtil determina- dos arquétipos binários (exterior/interior, seco/húmido, cultural/natural) e determina- das dicotomias tais como o domínio da esfera pública ou formal detido pelo homem face ao reduto privado, informal ou domésticoda mulher, a emotividade espontânea e natural feminina face à vertente racionalizante e cultivada masculina, reproduzindo a categorização binária mulher-natural-afectivo versus homem-cultural-racional. Estas dicotomias são hoje cada vez mais reequacionadas e desconstruídas na medida em que elas visam legitimar os poderes patriarcais na sociedade, compartimentando o formal e o informal, sobrevalorizando a esfera pública em detrimento da doméstica tida por periférica e banal, enfim, revalorizando o masculino como o quadro universal e primordial de referência e desvalorizando o feminino como elemento particular, secundário, derivado. ${ }^{3}$

7 Paralelamente às justificações legitimadoras através do (pseudo)argumento biológico, importa referir, nomeadamente em países de forte implantação católica, a função política e ideológica exercida pela Igreja Católica, a qual tem secularmente convivido com a defesa da ética e da moral patricêntrica ou mesmo patriarcal, a começar pela máxima de $\mathrm{S}$. Paulo: "Mulheres, obedecei aos vossos maridos". 
8 Uma outra explicação (pseudo)teórica, amiúde aduzida, assenta numa linha de interpretação freudiana, segundo a qual as diferenças do género centrar-se-iam, ao fim e ao cabo, na posse ou na ausência do pénis. Na perspectiva libertária de Freud (1975), o núcleo verdadeiro e autêntico da personalidade humana residiria no inconsciente (id), ou seja, no instinto libidinal que, enquanto pulsão de vida e princípio do prazer, estaria em confronto com o superego, o qual, com as suas normas e os valores culturais restritivos, constituiria o princípio da realidade, limitativo da realização do prazer, sublimando-se, quando muito, na criação artística ou cultural. o predomínio do princípio da realidade com todo o acervo de normas repressivas comportaria a negação do eros, do instinto libidinoso, enquanto princípio do prazer. Se os rapazes seriam induzidos a recalcar os seus impulsos libidinosos para com a mãe, as meninas seriam constrangidas a refrear a sua tendência erótica para com o pai e a identificar-se com a mãe.

9 À concepção freudiana reagiram, e com razão, diversas feministas para quem a identificação e a construção do género não implica apenas uma realidade biológica - que, de resto, não se reduz aos órgãos genitais nem se concentra apenas na fase de Édipo -, mas envolve uma construção social na qual intervêm várias componentes não biológicas. E, em relação à própria masculinidade, esta, adquirida à custa da separação da mãe, implicaria não um valor acrescentado mas uma perda emocional marcante.

10 Uma outra variante psicológica consiste em explicar a génese e o desenvolvimento da identidade e dos comportamentos masculinos e femininos pelos contextos de socialização familiar e escolar com os seus respectivos códigos normativos masculinos e femininos.

11 Por seu turno, também a sociologia se tem ocupado desta questão, embora com interpretações diferentes. Na óptica estrutural-funcionalista, numa versão mais elaborada e de cariz predominantemente axio-normativo, as diferenças biológicas e anatómicas dos órgãos sexuais masculinos e femininos são convertidas e erigidas em elemento constituinte das diferenças de género, pretendendo assim justificar ideologicamente a dominação masculina. Pertence à concepção estruturo-funcional (cf. Parsons 1956) em torno da família a velha e recorrente distinção entre a função instrumental levada a cabo pelo homem, tradicionalmente considerado o ganha-pão da família, e a função expressiva exercida pela mulher no âmbito doméstico, vista como o pólo afectivo-emocional dedicado ao cuidado do lar.

12 Avaliando, ainda que brevemente, esta visão, dela se pode inferir uma dimensão fortemente ideológica na medida em que ela tem reforçado e realimentado concepções conservadoras e até retrógradas sobre a família: a mulher, vista como "dona de casa" e "servidora do lar", "protegida" pela autoridade masculina, mantendo a função de cuidar material e afectivamente do marido e dos filhos e ficando, na prática, arredada dos processos de trabalho extradomésticos e de participação social e política na esfera pública.

13 Às visões estruturo-funcionais, que tendem a atribuir ao sistema o diferenciado conjunto de papéis masculinos e femininos, contrapõem-se as perspectivas interaccionistas e simbólico-valorativas (cf. Goffman 1974) que procuram trazer para primeiro plano não os invisíveis constrangimentos estruturais mas a presença dos actores sociais, ora masculinos ora femininos, as suas recíprocas interacções, a negociação dos papéis, a partilha das experiências e vivências, as quais são decisivas para definir e construir a própria identidade, ora masculina ora feminina. 

homens, detendo as alavancas do poder em vários níveis e instituições desde as centrais às locais e familiares, tendem a perpetuar-se nas instâncias de decisão em prejuízo das mulheres que detêm, em regra, um papel subordinado: em casa, na escola, no trabalho, na vida política, posição esta partilhada por uma considerável parte das feministas (cf. Roberts 1984). Esta linha explicativa remete-nos basicamente para a concepção weberiana centrada na análise das relações de autoridade e poder no seio dos grupos domésticos e sua articulação com a organização societal e a configuração dos diversos grupos sociais (cf. Weber 1978: 359, 365 ss). Weber (1978) realça, a respeito da formação da instituição familiar, como um local de regulação política e económica em torno do património sob a orientação do patriarca, que implica um controlo sobre o património e a sexualidade femininas. Esta posição é também subscrita por Segalen (1980: $60 \mathrm{ss),} \mathrm{Flandrin} \mathrm{(1984:} 8 \mathrm{ss}$ ) e sobretudo Bourdieu (1972: 1120, 1980: 238, 320 ss), segundo o qual as relações de autoridade e poder no interior das famílias pressupõem a existência de concorrência geradora de tensões e conflitos que ameaçam a unidade e a coesão domésticas. ${ }^{4}$ Porém, no quadro do modelo de poder, o autor que representou um especial suporte para as próprias teorias feministas foi de longe Foucault (1994) que mostra como operam, a nível infra-estatal, comunitário e doméstico, os mecanismos de poder quase invisíveis mas eficazes.

15 A posição marxista tem tradicionalmente assumido que as assimetrias sexuais se devem basicamente às desigualdades de classe e, no mundo de hoje, ao sistema capita- lista. À desigualdade sexual subjaz a divisão sexual do trabalho como uma das formas da divisão social do trabalho, a qual, embora variável consoante o modo de produção dominante, constitui a base de explicação das desigualdades sociais, designadamente das desigualdades de género. ${ }^{5}$ Há, porém, a destacar entre os fundadores do marxismo o avanço dalguns elementos teóricos relevantes em torno da divisão sexual do trabalho e, em particular, a dimensão histórica em relação à origem e à evolução da exploração e dominação da mulher que, segundo Engels (1980), prender-se-ia, por sua vez, com a origem da propriedade privada e do Estado.

A nível programático e político, para as organizações de inspiração marxista, sem excluir propostas realistas de reformas e inclusive sem deixar de apresentar iniciativas progressistas com propostas relevantes para a melhoria da situação da mulher, a solução estratégica deste problema passará contudo pela mudança radical da própria estrutura social e pela emancipação das classes trabalhadoras.

17 Num campo de intersecção da sociologia marxista e da psicanálise freudiana, importa também relevar a contribuição da teoria crítica da Escola de Francoforte desde Adorno et al. (1950) a Reich (1972) e Marcuse (1963), os quais, estabelecendo uma ponte entre a dialéctica hegeliana, o marxismo e o freudismo, identificaram o superego freudiano com as normas e os valores alienantes do sistema capitalista e explicaram os processos de dominação pelo recalcamento do eros, criando assim, nos termos de Marcuse (1968), o "homem unidimensional".

Quanto às abordagens feministas, importa diferenciar várias tendências desde o feminismo liberal que se situa numa óptica jurídico-política até ao feminismo radical que, rejeitando a perspectiva marxista em torno do conceito prioritário da exploração e dominação de classe, sustenta como primeiro conceito explicativo da diferenciação sexual o conceito central do género e das correspondentes contradições sócio-históricas 
centradas na dominação e, eventualmente, na exploração da mulher por parte do homem com toda a série de representações e estereótipos socialmente construídos.

Incidindo uma particular atenção no debate entre marxistas e feministas e, no seio destas entre marxistas-feministas e feministas-não marxistas, importa começar por refe- rir que a tradicional visão marxista, tendo-se focalizado demasiado na produção, quer de objectos, quer de seres da espécie humana, suscitou diversas críticas, particularmente da parte da teoria feminista que deslocou o acento tónico para a família como a instituição nuclear da reprodução social, a qual, a par ou em articulação com outras instâncias, criaria os mecanismos de suporte propiciadores das condições específicas necessárias à produção dentro e fora da casa.

Se é certo que o processo de industrialização e urbanização veio separar o local de residência e o local da profissão extradoméstica, pelo menos para a maioria dos membros activos da família o trabalho doméstico não pago, predominantemente exercido pela mulher, tem constituído na divisão social e sexual do trabalho, ainda que com variadas funções conforme o tempo e o contexto espacial, uma condição indispensável do próprio trabalho exercido pelo homem e, em particular, no quadro do modo de produção capitalista, uma base imprescindível para a acumulação e a expansão do capital, tal como o acentuaram e desenvolveram diversas autoras, sobretudo feministas de inspiração marxista. ${ }^{6}$ No entanto, a tradicional posição marxista não assumia o trabalho doméstico como

tema central da análise de dominação de género nem sequer o articulava adequadamente com a problemática da exploração de classe a nível global, considerando como improdutivo o trabalho doméstico, ou integrando, quando muito, a intermitência do trabalho doméstico e/ou do trabalho assalariado feminino no quadro da teoria marxista sobre o exército industrial de reserva. Outros, porém, como Braverman (1974), avançaram a hipótese de que a tendência de desqualificação do trabalho atingia, de modo particular, a força de trabalho feminina. Outras como Brown (1970) e Ortner (1988), com uma forte orientação feminista, assumiam que a explicação básica da dominação masculina residiria no facto de a mulher ter sido confinada aos papéis domésticos nomeadamente em torno das funções de maternidade.

Dada a insuficiência da interpretação marxista dominante, o feminismo radi- cal, desenvolvido sobretudo a partir dos anos setenta, veio sustentar que a contradição básica das desigualdades sociais residia analiticamente, não na contradição de classes mas antes na contradição de género, destacando assim a dominação patriarcal da mulher ao longo da história até hoje. Para as feministas radicais não-marxistas a relação de dominação e/ ou exploração patriarcal atravessa os vários modos de produção e, mesmo em relação ao capitalismo, apresenta uma lógica e uma dinâmica autónomas assentes ora nas diferenças sexuais biológicas e reprodutoras (Firestone 1976: 20 ss), ora na específica dominação patriarcal nas relações públicas e privadas (Walby 1997). Esta contradição homem-mulher seria por si só suficiente para dar conta das múltiplas e complexas formas de dominação em vários tipos de sociedades, explicando inclusive a oposição dos homens nas organizações sindicais tradicionais, a limitar a concorrência das mulheres nos mercados de trabalho.

Cada vez mais, porém, a linha mais fecunda de forma a superar as contradições de classe e de género, será mais uma vez a perspectiva marxista e weberiana. É nesta linha que Roberts (1984) e Hartman (1982), cruzando várias influências desde a weberiana à marxista, sustentam que o poder da mulher varia em função do grau de disposição sobre 
recursos e recompensas, do modo e da medida de participação no processo produtivo, do grau de mobilidade e presença/ausência de hierarquização de papéis sexuais na divisão do trabalho, sendo esta última variável um factor que, ao ser integrado na teoria das desigualdades sociais, exige, segundo Garnsey (1982: 427), uma reconceptualização das teorias da estratificação e das classes sociais.

\section{Poderes e representações sobre a sexualidade: breve retrospectiva histórica}

Se, até aos anos setenta, particularmente nos meios rurais, a sexualidade era um tema tabu, na antropologia e na sociologia era um assunto marginal e negligenciável ou, quando muito, o seu tratamento surgia subsumido como um assunto "desviante" no âmbito do parentesco, da família e do casamento. Um passo mais para a compreensão das diferentes interpretações acima delineadas exige que façamos um esforço conceptual no sentido de definir a sexualidade, sobre a qual não há contudo unanimidade.

o fenótipo sexual, constituindo uma base de diferenciação biológica entre homens e mulheres, serviu simultaneamente durante séculos como justificação ideológica de desigualdades sexuais. Porém, as legitimações ou argumentações têm diferido consideravelmente. Assim, enquanto nos círculos conservadores tópicos como sexualidade, prostituição, homossexualidade ou eram tabus ou eram desqualificados e verberados pela religião dominante em cada contexto espácio-temporal - em Portugal pela religião católica -, nas esferas ora liberais ora emancipatórias o continente da sexualidade era objecto de interpretações biogenéticas e psicológicas, em particular pela psicanálise de inspiração freudiana ou junguiana.

Se, numa óptica organicista, funcionalista e conservadora, a sexualidade era vista como um forte impulso carnal que, derivando de energias biológicas instintivas e inatas, deveria ser controlada, de modo a evitar os seus efeitos destrutivos e ameaçadores da moral e da ordem social vigente, já numa perspectiva libertária, a sexualidade, enquanto força libidinal irresistível, deveria irromper contra o repressivo sistema normativo dominante, não só presente nas sociedades tradicionais, como também na moderna civilização vitoriana, puritana (cf. Millet 1974). Em ambos os casos, a sexualidade era conceptualizada de modo essencialista como uma força biogenética imparável, próxima da natureza animal e, senão anticultural, pelo menos, meta-social e transcultural. Por um lado, na versão tradicional da maior parte das religiões nomeadamente da católica, a sexualidade, inerente ao corpo e embebida na "degradada" condição terrena do ser humano, só podia ser vencida pela força do espírito ou tolerada como mal menor pelo sacramento do matrimónio, destinado a santificar a relação conjugal e a própria família. A necessidade de controlo e domesticação da sexualidade, em particular da feminina, conheceu várias formas e expressões desde a mortificação do corpo na defesa das superiores virtudes da castidade e da virgindade, passando pelas práticas monogâmicas, até à posse e vigilância da honra feminina através do controlo da propriedade fundiária na herança e no modelo patriarcal de casamento.

Sem menosprezar os contributos valiosos de diversos autores, sobretudo da parte de Freud (1975) e seus seguidores, há que reconhecer que a essencialização naturalizada da sexualidade e outros fenómenos com ela relacionados viriam a ser desconstruídos por sociólogos, antropólogos, historiadores e outros cientistas sociais que começaram a 
encarar a sexualidade não apenas como um atributo ou propriedade de ordem biogenética ou psíquica mas como um produto social ou, como diria Foucault (1994), um construto histórico compreensível no seu contexto sociopolítico. A sexualidade é, segundo o autor, justamente um dos campos onde os diversos pode- res, nomeadamente, os institucionais, se exercem, seja de forma coerciva e impositiva, seja de modo subtil, sub-reptício, quase invisível, mas extremamente eficaz. Sendo o sexismo resultante das relações de poder na perspectiva foucaultiana, é compreensível que o movimento feminista tenha assumido, como referi, o pensamento deste autor como um dos alicerces do seu posicionamento face à sociedade patriarcal, concebendo assim a esfera das relações privadas ou (inter)pessoais de género como uma das expressões das relações de poder.

A diferença biológica e anatómica dos órgãos sexuais masculinos e femininos converteuse de elemento constituinte da sexualidade em justificação ideológica da dominação masculina, como referem, entre outros, Amâncio (1994) e Bourdieu (1998). Sem negar os "imperativos", as potencialidades biogenéticas e psíquicas, os desejos e as emoções, aliás possibilitadoras e, em regra, sempre presentes na actividade sexual, importa sublinhar, como o fazem Weeks (1986: 15 ss) e Nencel (1994), que a sexualidade não pode ser abordada como uma espécie de energia biopsíquica apenas derivada de genes, hormonas, instintos ou do inconsciente e, como tal, "naturalizada" e desligada do contexto social e histórico. Ela engloba um conjunto de possibilidades biológicas e mentais (identidade de género, diferenças corporais, capacidades reprodutivas, necessidades, desejos, fantasias, emoções, valores), que não necessitam de estar todas ligadas e, em certas culturas, não o estão. Por isso, contrariamente a uma abordagem fixista, determinista e reducionista de cariz ora biogenético ora psíquico, a sexualidade comporta várias dimensões que fazem de qualquer relação sexual uma relação social que, como qualquer outra, é socialmente condicionada, estruturada e construída, para usar a teorização de Luhman (1982), em diversos patamares: sócio-estrutural, organizacional e interaccional.

Para entender a sexualidade e o entendimento diverso dado ao comportamento sexual dos homens e das mulheres nomeadamente no meio rural, há que partir da ver- tente sócio-estrutural, ou, seja, da condição objectiva de vida dos respectivos grupos de pertença das mulheres - o que engloba a classe social, o género, a idade e demais recursos - e, em seguida, articulá-la com outros níveis, a saber, o político-organizacional no seio da comunidade e da casa e, por fim, o interaccional, o qual toca as próprias vivências, experiências e socialidades no seio de cada género e entre os membros dos géneros masculino e feminino. Contrariamente a autores que, de uma ou outra forma, essencializam e projectam, quer sobre os homens, quer sobre as mulheres, determinadas características ou atributos de cariz biogenético, psicológico ou sociomoral e cultural, importa, tendo em conta estas vertentes, relevar o processo relacional que, em determinado contexto histórico em termos socioeconómicos, políticos, culturais, permite compreender e explicar os comportamentos sexuais entre pessoas do mesmo sexo ou de sexo oposto.

30 A nível organizacional e político-administrativo, o maior ou menor grau de interferência institucional - eclesiástica e civil -, a maior ou menor dose de repressão patriarcal e administrativa com as mais variadas proibições e tabus, em particular sobre as mulheres, é dependente do tipo de sociedade e seu contexto espácio-temporal, das mentalidades, doutrinas e ideologias da época, sobretudo ao nível institucional e estatal, em relação aos comportamentos sexuais humanos. Vários autores, entre os quais Flandrin (1983) e Goody (1983), demonstraram que as origens da moral sexual ocidental remontam à cultura 
judaico-cristã, fundada no mito em torno de Adão e Eva (superioridade do homem, seduzido e forçado a trabalhar e sustentar a prole; inferioridade da mulher, sedutora mas destinada à função reprodutiva) e refundada nos primórdios do moralismo cristão, sobretudo entre os séculos VI e XI, cujos mentores eclesiásticos determinavam certos interditos ou períodos de continências sexuais nomeadamente sobre os dias, as circunstâncias e as formas de cópula conjugal ${ }^{7}$. Para os moralistas cristãos desta época cujas reminiscências eram visíveis ainda nas aldeias do Noroeste português sobretudo até aos anos setenta (cf. Silva e Van Toor 1988; Silva 1998) -, impunha-se que o espírito vencesse a carne lasciva. Por isso, além de exaltada a abstinência pela castidade celibatária, os prazeres sexuais eram condenados como comportamentos luxuriosos, selvagens, irracionais mesmo no quadro do casamento. A paixão era perigosa para o homem e para a sociedade, pois, se fornicar fora do casamento era um pecado muito grave, grave era também fazê-lo com paixão ardente com a própria mulher. Mais, não só a mulher era portadora de "imundas" impurezas (v.g., o sangue menstrual), como o próprio coito era fonte de impureza e, por isso, se questionava inclusive se a mulher grávida, devido não tanto à fecundidade mas ao acto sexual que a provocou, podia ser baptizada ( in Flandrin 1983: 87 ss, 99-100, 116-124)! A sexualidade só era, portanto, admitida, desde que útil à sociedade, para a procriação e, como tal, deveria ser regulada, contro- lada, domesticada. Se, como refere Goody (1983), desde o século V até à emergência da modernidade - e em sociedades agrárias como a portuguesa provavelmente até aos anos setenta do século XX -, a Igreja constituiu a principal instituição modeladora das regras e normas relativas ao casamento, ela virá progressivamente a ser substituída nessa função mas de forma laica pelo emergente Estado-Nação que, desde os séculos XVIII e sobretudo XIX, veio ganhando um crescente poder de regulação.

31 É tendo em conta o fundo da doutrina judaico-cristã que é possível compreender como determinadas condutas são consideradas normais, aceitáveis, e outras desclassificadas como anormais, desviantes ou até patológicas, um pressuposto que nos remete para as concepções funcionalistas nomeadamente durkheimianas acerca dos factos sociais normais e patológicos. Aliás, a este respeito, o próprio Durkheim (1974) deixava de ser o sociólogo que pretendia explicar o social pelo social para cair na armadilha filosófica essencialista, ao assumir que o homem, bem como a mulher, sendo "por natureza" devasso ou possuindo apetites desenfreados nomeadamente os sexuais, carecia de alguma forma de controlo e regulação. Por isso, segundo Durkheim (1977), se a religião e as diferentes comunidades eclesiásticas, nomeadamente a católica, constituíam, nas sociedades agrárias tradicionais, e em articulação com Estados de cariz conservador ${ }^{8}$, as principais instituições reguladoras de fenómenos "desviantes" ou "patológicos", nas sociedades modernas teriam de ser, a par da família, da escola e dos corpos profissionais intermédios dos próprios cidadãos, as instituições públicas estatais que, directamente ou através de corpos profissionados tais como o policial, o judicial e o médico, deveriam regular e controlar o amplo campo bio-social e político da sexualidade. ${ }^{9}$

Os padrões de comportamento sexual inculcados nos processos de socialização são, em regra, diferentes por sexo: enquanto as mulheres são educadas no sentido de associar a actividade sexual à intimidade emocional, os homens são induzidos a dissociar o dito impulso sexual e a emoção, suscitando neles diferentes representações e significa- dos da feminilidade: desde a mulher como objecto de prazer, associado à fêmea animal com uma sexualidade potencialmente transgressiva e disruptiva, passando, por vezes, por arquétipos (v.g., "mulher-serpente") e estereótipos (a "mulher-puta"), até à figura 
virtuosa e protectora de "esposa" e "mãe", paradoxalmente assexuada e sublimada como fonte de vida (v.g., a procriação, o leite materno). Tal como já o fizera Segalen (1983) para o contexto rural francês, tais códigos morais e culturais terão certamente de ser articulados com a própria estrutura social e económica das sociedades agrárias nomeadamente mediterrânicas e, em particular, com a correlativa necessidade de preservação do património fundiário, como salienta J. Schneider (1971) e, por fim mas não menos importante, com o dominante carácter patricêntrico nas casas destas comunidades. ${ }^{10}$

Os resultados de vários estudos, constatando uma competição interna entre marido e mulher pelo controlo do poder doméstico, terão de ser compreendidos e explicados, quer a partir do volume de recursos ${ }^{11}$ que cada partido traz consigo para o casa- mento e/ou adquire na pendência do mesmo, quer sobretudo devido aos mecanismos tradicionais de subordinação política e ideológica feminina. Entre estes cabe especial referência ao designado binómio cultural da honra e da vergonha que, na base de certos atributos de ordem sexual, pressupõe como interdependentes e complementares papéis e funções social, económica e politicamente desiguais entre homens e mulheres.

Ao longo do tempo têm-se reproduzido e legitimado estas e outras normas e valores estereotipados acerca do comportamento masculino e feminino: o homem como elemento activo e assertivo, do ponto de vista social, profissional e sexual; a mulher como o elemento passivo, com um papel restrito à esfera doméstica, a quem o binómio honravergonha ${ }^{12}$ é avaliado e aplicado de modo negativo e defensivo (tabus, proibições, defesa da virgindade). Nos padrões tradicionais de socialização entre rapazes e raparigas as imagens construídas sobre a mulher como criatura subordinada, sexualmente insaciável e perigosa e, portanto, carenciada de protecção para manter-se casta e virgem antes do casamento, bem como a assunção do seu papel de recatada esposa e mãe de filhos, voltada para o interior da casa, serviam efectivamente a ordem social vigente e, em parti- cular, o poder masculino. Assim, enquanto os "desvios" ou "aventuras" masculinas em matéria de comportamento sexual, além de justificadas pela "impulsividade natural" masculina, não afectavam a honradez do homem-"prevaricador", podendo mesmo ser objecto de encómio, a mulher, transgredindo, ficava indelevelmente marcada, emocional e economicamente sobrecarregada na comunidade, nomeadamente sempre que surgiam filhos ilegítimos de relações sexuais não convencionais ou oficialmente aprovadas. Do mesmo modo, enquanto ao rapaz era-lhe tolerada e até estimulada e mesmo premiada qualquer aventura sexual extravagante e atrevida, à mulher era-lhe recomendada ou até imposta a contenção sexual, sendo-lhe refreados e reprimidos os seus apetites sexuais não só por parte dos padres - os "empresários da moral" na terminologia de Becker (1968) -, mas inclusive por parte da família e, em particular, dos pais.

Contrariamente à interpretação culturalista defendida por autores como Pitt- Rivers (1988), Peristiany (1988) e, até certo ponto, Cabral (1991), o código de honra-vergonha nomeadamente no campo sexual não possui apenas uma dimensão cultural mas é interdependente e condicionado por outros factores que se prendem, como refere Cole (1991), com a posição económica e social da mulher-trabalhadora e com a ideologia católica da dominação e sujeição da mulher pelo homem. Apesar da pertinência da desconstrução teórica e ideológica do binómio cultural honra-vergonha, como o faz Cole (1991), é importante reter que tal construção não era contudo apenas ideológica, mas fazia parte de uma realidade económica e social vivenciada no quotidiano das socie- dades rurais, sobretudo mediterrânicas, até recente data. Por isso, tais códigos culturais não 
podem ser evacuados simplesmente como espúrio factor ideológico na medida em que tais códigos, mesmo quando não totalmente concordantes com a realidade, estavam nela incorporados. A manutenção do código da honra-vergonha na sociedade rural portuguesa, entre outras, tem representado uma forma de dominação dos grupos sociais mais providos e, em especial, dos homens desses grupos sobre as respectivas mulheres. Se as mulheres sem recursos fundiários, quando transgressivas, eram dadas como "mulheres sem vergonha", as demais, podendo herdar ou tendo herdado bens patrimoniais, eram obrigadas a observar comportamentos sexuais condizentes com o seu estatuto, ora de potenciais candidatas a bons casamentos, ora de esposas herdeiras e conformadas às normas dos grupos sociais dominantes. A este respeito será interessante salientar que o princípio da articulação entre honra e posição social é mais aplicável às famílias abastadas, uma vez que, no caso das famílias pobres e assalariadas, ele é, tal como o referiu Cutileiro (1977), derrogado: as criadas e as mulheres dos trabalhadores assalariados, por motivos de dependência clientelar, podiam ter relações sexuais com os patrões dos seus maridos, mesmo, amiúde, com o conhecimento destes últimos.

A política sexual reemerge hoje como objecto de disputa e mobilização políticas, inclusivamente partidária, por um lado, entre conservadores restritivos e hostis à educação sexual e às sexualidades alternativas e, por outro, além dos liberais permissivos e praticantes destas práticas alternativas, protagonistas de correntes contestatárias de cariz ora moderado (socialistas), ora mais radical (marxistas e feministas). Graças às lutas e aos movimentos sociais conduzidos por estas últimas forças contra as políticas e ideologias conservadoras têm-se registado alguns avanços nas políticas sexuais, os quais para uns representam uma forma de incorporação desses movimentos e para outros conquistas e plataformas para novas reivindicações.

\section{Desigualdades de género em Portugal: um breve olhar}

Fazendo uma breve retrospectiva, designadamente para a sociedade portuguesa até aos anos oitenta e sobretudo até 1974 e tendo em conta alguns resultados de estudos realizados por sociólogos, historiadores e antropólogos e outros cientistas sociais em relação à sociedade portuguesa, podemos constatar processos de dominação patrimonial e masculina sobre mulheres, nomeadamente em meio rural: as mais providas para preservar e reforçar o património da casa, as menos providas e sobretudo as desprovidas como objecto de dominação dos homens sobretudo dos originários dos grupos sociais mais providos. Estes processos de dominação não excluem contudo a emergência, ainda que de modo latente, informal ou "infrapolítico", de "registos ocultos" (cf. Scott 1990), denotativos de práticas e estratégias alternativas e visões contra-hegemónicas, neste caso por parte das próprias mulheres ("intuições" dissidentes, "subversões" informais). Assim, inquirindo sobre o fenómeno da ilegitimidade e questionando sobre qual a condição, quer dos pais biológicos, quer das mães solteiras, constatamos a desigualdade sexual e o tratamento social diferenciado e discriminatório para com as mulheres, conclusão esta retirada de vários estudos. Por exemplo, em Fontelas, nome fictício de uma aldeia de Trás-os-Montes, O'Neill (1984) constatou como, ao longo de gerações, num sistema de herança indiviso ou avantajado, os pais dos filhos ilegítimos - até meados do século XX com percentagens de cerca de 30\% - eram, por norma, filhos de proprietários-lavradores não-herdeiros, enquanto as mulheres eram, em regra, jornaleiras. 

verificaram desde meados do século XIX, quer em sistemas de herança avantajados, quer em sistemas de herança divisa, como mulheres destituídas (criadas, jorna- leiras ou camponesas muito pobres) eram mães solteiras de filhos ilegítimos - em índices, ainda que menores, próximos dos de Trás-os-Montes, sobretudo no Alto Minho -, cujos pais biológicos eram, quando não lavradores-proprietários, guardas fiscais e florestais, comerciantes e até artesãos e operários com rendimentos fixos.

Em notável contraponto com os comportamentos tradicionais entre géneros, poder-se-á dizer que a consideração das dimensões espacial e sobretudo temporal permite-nos hoje relativizar ou até abandonar a rigidez conceptual dos valores centrados na honra e na vergonha. Para tal contribuíram decisivamente o êxodo rural e, em particular, a mobilidade geo-social da mulher em direcção aos centros urbanos nacionais ou estrangeiros, a diluição das fronteiras rural-urbano, o aumento dos níveis de escolaridade, o impacto dos meios de comunicação social e as mudanças de mentalidade, factores estes que induziram a alterações nos comportamentos e modos de relacionamento entre homens e mulheres (cf. Wall e Almeida 2001). Já não é assim tão premente a carga coerciva do binómio cultural honra-vergonha sobre a mulher, quer sobre a mulher casada, quer sobretudo a jovem solteira. Quanto à mulher casada - salvo o caso de eventual adultério que continua sendo assunto tabu e severamente reprovado, embora nem sempre necessariamente objecto de ostracismo comunitário -, já não está sujeita a pressões tão asfixiantes como outrora. A mulher frequenta mais o café e outros locais públicos nomeadamente nas vilas e cidades envolventes, mesmo sem a companhia do marido; imiscui-se mais na esfera pública em assuntos não só religiosos como políticos, sobretudo locais. É, porém, no comportamento da rapariga solteira onde é possível destilar uma visível descompressão do complexo honra-vergonha e a subsequente libertação das tradicionais normas que inibiam ou aprisionavam a sua congénere de há trinta anos. Auferindo amiúde, dentro e sobretudo fora da aldeia, rendimento próprio, ela permite-se iniciativas sem o controlo paterno ou fraterno em certas saídas, por vezes nocturnas, nos fins-de-semana, para as aldeias circunvizinhas e cidades (festas, discotecas, boîtes), assim como, na própria aldeia, frequenta cafés e namora mais livremente sem dar tantas satisfações à família. De resto, em bastantes eventos e ocasiões, já não há a rígida separação de divisão de tarefas e de espaços como outrora. Não só cada um dos sexos assume tarefas que eram tradicionalmente atribuídas ao sexo oposto, como se foi esbatendo a antiga separação de espaços, por sexos, na igreja (homens à frente, mulheres atrás), nas procissões e nas lojas e cafés. Este processo é todavia lento, constatando-se, tal como o faz notar Santos (1994: 87), uma considerável discrepância entre a igualdade formal reconhecida em texto legal e as práticas de assimetria sexual, a começar pela desigual distribuição de tarefas domésticas, entendidas no imaginário tradicional e nas práticas quotidianas como funções predominantemente atribuíveis às mulheres. Apesar de os homens, sobretudo nas gerações mais novas, participarem em maior medida nas tarefas domésticas, são as mulheres de longe as mais sobrecarregadas com tais tipos de trabalho. Na esfera da participação pública, seja na política, seja nos meios de comunicação, as mulheres, não obstante estarem académica e profissionalmente habilitadas, protagonizam, em bastante menor grau, processos de liderança e mobilização cívica e política (Dinâmia 1997; Viegas e Faria 1999: 66).

As mudanças, quer ao nível social e económico, quer, embora mais lentas, ao nível das mentalidades, vão contudo operando na sociedade. As mulheres, além de conseguirem o 
reconhecimento de igualdade em termos legais, vêm engrossando as fileiras dos diversos mercados de trabalho extradomésticos como assalariadas, passando, em Portugal, de cerca de 18\% em 1960 para 44\% em 1992 (Mendes 1997: 130). A elevada taxa de feminização do emprego em Portugal - aliás a terceira maior da Europa nas faixas etárias dos 25 aos 49 anos - deve-se a vários factores: necessidade de complementar baixos salários dos homens nos agregados domésticos; factores de ordem histórica como a importância da pequena agricultura camponesa, sobretudo a partir da eclosão da guerra colonial e das vagas emigratórias a partir dos anos sessenta; e, por fim mas não menos importante, o processo, ainda que lento, de consciencialização das mulheres a reivindicar um lugar de realização e/ou revalorização profissional extradoméstica sobretudo a partir do 25 de Abril e, em particular, por parte de mulheres escolarmente qualificadas (cf. respectivamente Ferreira 1999; Cabral 1997: 89).

41 Além disso, do estudo de Mendes (1997: 144 ss) constata-se que, quando analisada a mobilidade social das mulheres não tanto a partir da situação de classe dos maridos e/ou famílias de origem mas mais a partir da sua própria profissão, há menores obstáculos para a mobilidade intergeracional nomeadamente a partir das permeabilidades possibilitadas pelas qualificações, o que tem sido visível pelo aumento exponencial da feminização no sistema de ensino. Embora nos graus de ensino básico e secundário as mulheres acima dos 35 anos conheçam taxas percentuais de sucesso menores que os homens, elas têm vindo a superar os homens na obtenção de diplomas de cursos superiores e em várias categorias sociais (cf. Mendes 1997: 149). Transversalmente a várias classes e grupos sociais, embora afectando mais os assalariados, dever-se-á apontar, ainda que de modo sucinto, as desigualdades sexuais na estrutura de emprego, em que a maioria das mulheres portuguesas, além de conhecer uma distribuição desigual no mercado de trabalho (41,4\% contra 58,6\% de homens), ${ }^{13}$ se localiza nas áreas e nas profissões menos rentáveis e pior remuneradas. Ainda que em menor medida que noutros países europeus, que conheciam valores de segregação sexual da mão-de-obra acima dos 40\%, Ferreira (1993: 239) constata em diversos sectores de emprego em Portugal uma taxa de $35 \%$, a qual se deve a uma menor taxa de assalariamento e a uma taxa mais elevada de trabalhadoras autónomas nomeadamente na agricultura (27\% do total) do que na Europa.

Algumas ocupações profissionais tais como a magistratura, a carreira militar, diplomática ou empresarial foram no passado vedadas ou obstaculizadas às mulheres e, mesmo após o 25 de Abril de 1974, têm sido na prática dificultadas. A participação política nos governos, mais como secretárias de Estado que como ministras, não ultra- passou os 10\%, ficando-se entre os $3 \%$ e os $5 \%$ até 1981 e, à excepção do XII governo constitucional com $10 \%$ de mulheres, entre os 5\% e os 8\% entre 1981 e 1995 (Viegas e Faria 1999: 49-50). A nível parlamentar, ocorrem situações semelhantes: as percentagens de candidaturas femininas situam-se na ordem dos $10 \%$ a $15 \%$, mas as percentagens das eleitas fixam-se numa taxa inferior - entre 4\% e 11\% ao longo de cerca de vinte anos (Viegas e Faria 1999: 54-55).

Não obstante alguns consideráveis avanços e melhorias nas posições relativas das mulheres, importa reter que, para além do facto de a integração no mercado de trabalho conhecer para as mulheres um elevado grau de precarização, segmentação e até segregação sexual ${ }^{14}$, em certos sectores (v.g., têxtil, ensino, segurança social, agricultura) existem ainda consideráveis barreiras para a inserção e realização profissionais das mulheres: o menor grau de escolaridade básica e secundária, a que acresce a insuficiência de infra-estruturas sociais estatais e, em particular, a baixa cobertura da rede pública de 
ensino pré-escolar e sobretudo ATL. Por outro lado, verifica-se uma sub-representação de mulheres e baixo grau de participação nos lugares de chefia em determinados sectores da vida económica e sobretudo em órgãos do poder político (cf. Freire 1998; Viegas e Faria 1999), ${ }^{15}$ situações de discriminação salarial e - por fim, mas não menos importante - a desigual repartição das tarefas domésticas, bem como a sujeição a práticas discriminatórias e não raro de violência, denotativas, por sua vez, da frequente distribuição desigual do poder em favor do homem e em prejuízo da mulher. Mesmo quando as mulheres têm conquistado, ora através de movimentações sociais, ora a pulso em termos individuais, determinados lugares socioprofissionais, tal ocorre, nomeadamente em Portugal, graças a um elevado preço em sobretrabalho doméstico, para além de eventuais processos de hetero-estigmatização e autoculpabilização de menor dedicação à família e, em particular, aos filhos.

\section{Género e classe: por uma articulação conceptual pluridimensional}

45 A tradicional visão marxista, tendo-se focalizado demasiado na produção, quer de objectos, quer de seres da espécie humana, suscitou diversas críticas, particularmente por parte da teoria feminista que deslocou o acento tónico para a família como a instituição nuclear da reprodução social, a qual, a par ou em articulação com outras instâncias, criaria os mecanismos de suporte propiciadores das condições específicas necessárias à produção dentro e fora da casa.

Avaliando as várias concepções sobre as desigualdades de género atrás referidas, considero extremamente aliciante o debate recorrente entre os marxistas e as feministas, propondo a este respeito um "casamento" político que, após os primeiros encontros informais e outros, na luta prática diária, conduza a equacionar e articular de modo fecundo o velho-novo problema em torno da relação entre classe e género.

Em primeiro lugar, está em causa a perspectiva tradicional marxista que, ao centrar-se no modo de produção, secundarizou ou subestimou o processo de reprodução que, em relação às questões do género é nuclear, sendo possível fundamentar esta posição a partir duma nova leitura dos próprios escritos de Marx e Engels desde a Ideologia Alemã (1972), passando por 0 Capital (Marx 1974) até à Origem da família, da propriedade privada e do Estado de Engels (1980), sendo talvez nesta última obra que surge com maior clareza a centralidade determinante não só da produção como da reprodução social: "De acordo com a concepção materialista da história, o factor decisivo na história é, em última instância, a produção e a reprodução da vida imediata. Mas essa produção e essa reprodução são de dois tipos: de um lado, a produção dos meios de subsistência, de produtos alimentícios, roupa, habitação e instrumentos necessários para tudo isso; do outro lado, a produção do próprio homem, a produção da espécie" (Engels 1980: 8).

Tal como na relação entre o modo de produção capitalista e os demais modos de produção não capitalistas (camponês, artesanal, tributário), em que estes são subsumidos e incorporados por aquele sob formas de coexistência subalternizada em função da necessidade de reprodução e expansão do capitalismo, assim também o trabalho doméstico, histórica e usualmente feminino, desempenha um papel crucial na criação de valor, servindo assim os objectivos de produção e de reprodução do sistema. Trata-se assim da articulação entre o trabalho assalariado fora de casa e das formas de trabalho 
doméstico não capitalistas utilizadas pelo próprio modo de produção capitalista, perspectiva esta que obriga a abandonar a homologia dual segundo a qual, enquanto ao homem pertenceria a esfera da produção, à mulher caberia a esfera da reprodução.

$\mathrm{O}$ próprio conceito de reprodução social aplicado à economia e à sociedade com- porta inexoravelmente, nas esferas da produção, distribuição e consumo, relações e trocas, quer dos seres humanos entre si, quer destes com a natureza e os ecossistemas envolventes, processos e relações que se repercutem nas próprias relações interfamiliares e intradomésticas. Nesta óptica, o processo de reprodução implica processo de produção e vice-versa: "Nenhuma sociedade pode deixar de consumir, nem pode, portanto, deixar de produzir. Por conseguinte, todo o processo social de produção considerado nos seus constantes vínculos e no fluxo ininterrupto de sua renovação é, ao mesmo tempo, um processo de reprodução" (Marx 1974: 515).

Para Harris e Young (1981: 113) dever-se-ão distinguir três sentidos de reprodução social consoante a amplitude e o nível de abstraç̧ão envolvidos: (i) enquanto reprodução duma determinada sociedade ou formação social; (ii) enquanto reprodução

da força de trabalho; (iii) enquanto forma de produção de seres humanos, ou seja, de reprodução biológica da espécie. Se esta última constitui uma condição necessária da reprodução da formação social, as condições e respectivas taxas de reprodução humana não derivam simplesmente da reprodução da sociedade como um todo. Do mesmo modo, a reprodução do trabalho adequadamente socializado é igualmente condição necessária mas não suficiente da reprodução social, pelo que implica os portadores de relações sociais específicas, incluindo também os não produtores. Enquanto o conceito de reprodução social na primeira acepção, em termos sistémicos e ao nível mais abstracto aliás tratado por Marx (1974) ao analisar o circuito recorrente da reprodução do capital (produção-circulação-consumo-produção) -, pressupondo ou não as relações do género, não exige necessariamente a diferenciação homem-mulher, nos dois subsequentes sentidos a inclusão da discussão sobre o género torna-se imprescindível, uma vez que é sob condições concretas de dominação e subordinação capitalista não só de homens por homens mas também de género (ou seja, de mulheres por homens e de homens por homens quanto ao controlo da circulação/distribuição das mulheres) que a reprodução alargada do capital ocorre e, eventualmente, se intensifica. Consequentemente, para dar conta das desigualdades de género, o clássico conceito de classe é insuficiente ${ }^{16} \mathrm{e}$, por isso, terá de ser requestionado, reequacionado e complementado com outras categorias específicas e, neste caso, por categorias associadas ao género. Os processos de acesso e controlo do trabalho em sociedades não capitalistas são co-determinados não tanto nem sobretudo por critérios do mercado de trabalho, mas mais por factores tais como as relações de parentesco, filiação, idade, controlo sobre o processo de circulação, prestígio e outros (cf. Meillassoux 1977). Donde, o controlo quer sobre o trabalho, quer sobre a sexualidade feminina e a capacidade reprodutiva das mulheres, quer ainda sobre a força de trabalho destas e da dos seus próprios filhos nomeadamente através do casa- mento, difere de sociedade para sociedade, sendo estes aspectos todavia centrais para aferir a importância das relações do género para a reprodução social.

É nesta óptica que Harris e Young (1981: 124 ss), procurando suprir uma lacuna na tradição marxista e na própria antropologia em geral mais ocupada com os mecanismos de transmissão da propriedade, assinalam a importância fulcral da reprodução do trabalho, a qual, sendo condição sine qua non da reprodução social, abrange três aspectos: (i) a alocação e a subsequente reprodução dos indivíduos através de práticas matrimoniais 
predominantemente endogâmicas no seio de determinada classe; (ii) a reprodução ideológica do trabalho adequadamente socializado em determinadas práticas, normas e valores culturais, o que é cultivado a partir das primeiras fases do processo de socialização doméstica e escolar, aspecto este destacado por Bourdieu e Passeron (1977); e (iii) a manutenção quotidiana das condições de vida materiais (alimentação, vestuário, "recreação"); enquadrado nestes aspectos, o tradicional trabalho doméstico feminino e as demais condições da estrutura da família têm sido cruciais para os processos não só de reprodução como de produção. Embora, em qualquer destes três aspectos, a mulher ocupe uma posição central, o trabalho doméstico, entendido numa visão androcêntrica como trabalho apenas reprodutivo, subsumido no chamado sector informal ou enquadrável no trabalho dito comunitário, amiúde considerado de baixo estatuto social e até, por vezes, não-trabalho, constitui parte integrante, a par doutros serviços das políticas sociais, do processo global de reprodução do trabalho em benefício do capital.

Como referem Rapp (1983: 34 ss) e Heller (1986), os processos de reprodução em determinados sectores (v.g., camponês, artesanal) têm lugar simultaneamente não só na esfera produtiva extradoméstica, mas também nas tarefas propriamente domésticas no quotidiano, cuja responsabilidade, programação e execução acabam, conforme a tradicional ideologia em torno do género, por ficar predominantemente a cargo da mulher. Nesta óptica, a já referida retrógrada e proto-burguesa visão (neo)parsoniana, no sentido de fixar a figura feminina como simples e única componente expressiva da família em subalterna complementaridade com a componente instrumental masculina, enquanto angariador dos meios de subsistência, foi com pertinência refutada por diver- sos autores, entre os quais Hareveen (1982: 2 ss, 1976: 190 ss) e Poster (1979: 102). Uma tal concepção pode ser reveladora do modelo teleológico das famílias das classes intermédias e até mesmo assalariadas, mas é flagrantemente denegada e contrariada pela divisão sexual do trabalho na época do capitalismo tardio e mais ainda nas economias e sociedades agrárias ou em contexto de transição para o capitalismo. Aqui a mulher, além de herdar e coorientar a casa em termos aproximados aos do marido, é activa nas diversas tarefas produtivas extradomésticas (cf. Silva 1998: 127). Além disso, as próprias tarefas estritamente domésticas, fazendo, directa ou indirectamente, parte integrante dos processos produtivos não só dentro como fora de casa, criam condições necessárias à continuidade dos processos produtivos extradomésticos no quadro das próprias formações sociais capitalistas.

54 A dominação patriarcal e correlativa subordinação da mulher não é apenas ideo- lógica nem sequer apenas política mas assenta nas esferas de produção e de reprodução e, por outro lado, abarca também outras esferas da vida social, em suma, nas condições de vida objectivas - um conceito mais amplo do que o de classe, como veremos de seguida. Tal como refere Bourdieu (1998), as diferenças de género são construídas na base da "justificação natural da diferença socialmente construída entre géneros e, em particular, da divisão sexual do trabalho", tornando-se assim "uma construção social que encontra o seu princípio nos princípios de divisão da razão androcêntrica" (Bourdieu 1998: 16, 21). ${ }^{17}$ Tem sido esta visão patri-androcêntrica a alimentar a velha dicotomia entre o lado formal e público ocupado pelo homem e o lado informal e privado feminino, valorizando o primeiro em detrimento do segundo e, mesmo quando seja detectável um

55 certo poder informal e "oculto" da mulher, como o referem Riegelhaupt (1967), Reiter (1975) e Segalen (1980), ele visa ainda reproduzir a dominação masculina na casa e sobretudo na esfera pública. ${ }^{18}$ 
56 A análise das relações de exploração e dominação da mulher deverá articular os conceitos de classe e de género e, tendo em conta a constante tensão entre constrangi- mentos estruturais e escolhas racionais, terá de ser balizada, estruturada e articulada a três níveis:

(i) ao nível sócio-estrutural, ou seja, na base da condição objectiva de vida dos respectivos grupos de pertença das mulheres - o que engloba não só o género mas também a classe social, a idade e demais recursos. Deste modo, as relações de exploração e dominação das mulheres terão de ser analisadas com base nas contradições inerentes aos conflitos de classe e de género na respectiva sociedade classista e patriarcal, quer em termos diacrónicos, quer em termos sincrónicos, o que, para além de apresentar pontos de convergência com a exploração e dominação de homens, pode apresentar formas específicas de dupla exploração e dominação da mulher na segmentação do mercado de trabalho, bem como na divisão do trabalho nos diversos sectores produtivos, incluindo o doméstico;

(ii) o nível político-organizacional, que pressupõe relações de subjugação e dominação das mulheres no âmbito das mais diversas organizações desde o local de trabalho extradoméstico (comunidade, empresa/instituição) aos partidos políticos e outras organizações, passando pelo contexto organizacional doméstico, em que as mulheres, na sua grande maioria, primam pela (quase) ausência de poder, deliberada ou não, ou detêm uma posição hierarquicamente subordinada, reforçando assim o lado sócio-estrutural; (iii) o nível interaccional, o qual toca as próprias vivências e experiências, interacções e sociabilidades não só entre diversos grupos de pertença no seio de cada género mas também entre membros do género masculino e feminino, relações e interacções em que as mulheres são amiúde desvalorizadas, desclassificadas ou mesmo discriminadas, o que ocorre nos locais de trabalho, nas relações em público e sobretudo nas relações domésticas, em privado, ou seja, na micro- política doméstica.

Embora cada um destes níveis de análise possua uma relativa autonomia, dever-se-á dar prioridade analítica ao nível mais abstracto (o sócio-estrutural), passando pelo organizacional, até ao interactivo (o menos abstracto), articulando os dois conceitos classe e género - e enfatizando um ou outro conforme a configuração social em causa e em função das situações concretas. Nesta óptica, a dominação patriarcal assume formas diversas consoante não só as relações de género mas também os modos de produção presentes e, em particular, o modo de produção dominante em cada sociedade, tempo e espaço.

As correntes organizacionais, de poder, e sobretudo as perspectivas interaccionistas têmse ocupado respectivamente do segundo e do terceiro níveis e, por estar mais próximo da vida quotidiana, esquecem amiúde os parâmetros estruturais da exploração sexual e sobretudo de classe, atribuindo não raro ao homem "culpas" e "responsabilidades" quando ele é também amiúde vítima dos constrangimentos estruturais do sis- tema. Em contrapartida, a visão marxista-leninista tradicional, ao focalizar a análise da exploração e da dominação femininas, em termos sócio-estruturais, com acento (quase) exclusivo nas contradições de classe, obnubila, subestima ou relega para segundo plano as vertentes organizacionais e sobretudo a dimensão interactiva, desresponsabilizando o homem nas formas de dominação quotidiana, onde, para além das eventuais relações de exploração, ocorrem com frequência associações selectivas e práticas de discriminação sexual, em regra em detrimento da mulher. A este nível, podem contudo ocorrer excepcionalmente relações de dominação inversa por parte de mulheres para com homens nomeadamente 
em contexto doméstico, sendo de evitar, portanto, generalizações abu- sivas. Se, num considerável número de casas, nomeadamente em Portugal, se verificam, a par de situações de relativa reciprocidade e simetria sexuais, situações de dominação, opressão e até violência por parte de homens face às "suas" mulheres, também a dominação, ainda que em termos minoritários, do homem pela mulher, é também real, tal como pude constatar designadamente em meio rural minhoto (Silva 1991). A redistribuição da conflitualidade intradoméstica e, em particular, conjugal, designadamente na modalidade heterossexual, centra-se em torno do poder doméstico, o qual é construído a partir da divisão social do trabalho fora e dentro de casa, do tipo e grau de recursos materiais e simbólicos, como referi atrás.

A eliminação das desigualdades de género, como realidade não estritamente biológica mas social e politicamente construída, se, por um lado, pressupõe não só a mudança de mentalidades no homem e na mulher mas também a construção de poder feminino através das suas organizações específicas (de que, por exemplo, a imposição legal duma quota mínima de lugares pode ser um passo), por outro, tal objectivo estratégico convoca necessariamente o concurso das lutas sociais com base no critério de classe, ou melhor dito, dos interesses das classes e dos grupos sociais explorados e oprimidos.

Perante a imperiosa necessidade da luta pela igualdade de tratamento entre homens e mulheres e de acesso prático a direitos e oportunidades não só na esfera extradoméstica e pública como na doméstica e privada, urge, em termos teórico-práticos e tendo em vista a emancipação das mulheres enquanto cidadãs e trabalhadoras, um fecundo cruzamento matrimonial entre feminismo e marxismo, o qual constitui(rá) certamente o prelúdio e o contributo teórico prático para uma das maiores mudanças societais e políticas no próximo futuro.

\section{BIBLIOGRAFIA}

ABOTT, Pamela and WALLACE, Claire (1991), Gender, Power and Sexuality, Basingstoke: Macmillan. ADORNO et al. (1950), The Authoritarian Personality, Nova Iorque:Harper and Brothers.

ALMEIDA, Miguel Vale de [2000 (1995)], Senhores de Si. Uma interpretação antropológica da masculinidade, Lisboa: Fim de Século.

AMÂNCIO, Lígia (1993), “Género - Representações e identidades” in Sociologia - Problemas e práticas , 14: 127-140.

AMÂNCIO, Lígia (1994), Masculino e Feminino. A construção social da diferença, Porto: Afrontamento.

BECKER, Howard S. \{1968(1963)\}, Outsiders - Studies in the Sociology of Deviance. Nova Iorque e Londres : The Free Press of Glencoe.

BOURDIEU, Pierre (1972), "Les stratégies matrimoniales dans le système de reproduction", in Annales, ano XXVII, 4-5: 1105-1127.

BOURDIEU, Pierre (1980), Le Sens pratique, Paris: Minuit. 
BOURDIEU, Pierre (1998), La Domination masculine, Paris: Seuil.

BOURDIEU, Pierre et PASSERON, Jean Claude (1977), Reproduction in Education, Society and Culture, Londres: Sage.

BRAVERMAN, Harry (1974), Labour and Monopoly Capital. The Degradation of Work in the Twentieth Century, Nova Iorque: Londres.

BRENNER, Johanna e LASLETT, Barbara (1986), "Social Reproduction and the Family" in U. Himmelstrand (org.), Sociology: From Crisis to Science?, vol. II, The Social Reproduction of Organisation and Culture: 116-131, Londres: Sage Publications.

BRETTEL, Caroline (1991), Homens que Partem, Mulheres que Esperam. Consequências da emigração numa freguesia minhota, Lisboa: Publicações Dom Quixote.

BROWN, Judith (1970), "A Note on the Division of Labor by Sex", in American Anthropologist, vol. 72, 5: 1073-1078.

CABRAL, João Pina (1989), Filhos de Adão, Filhas de Eva. A visão do mundo camponesa do Alto Minho, Lisboa: Dom Quixote.

CABRAL, João Pina (1991), Os Contextos de Antropologia, Lisboa: Difel.

COLE, Sally (1991), Women of the Praia, Princeton, Nova Jersey: Princeton University Press.

COSTA, Adélia (1992), Representações de Homens e Mulheres, Portugal 1991, Lisboa: Comissão para a Igualdade e para os Direitos das Mulheres.

CROMPTON. Rosemary (2003), "Class and Gender beyond the "CulturalTurn”" in Sociologia. Problemas e práticas, 42: 9-24.

CUTILEIRO, José (1977), Ricos e Pobres no Alentejo, Lisboa: Sá da Costa.

CUTILEIRO, José (1988), "Honra, vergonha e amigos" in J. G. Peristiany (org.) Honra e Vergonha. Valores das sociedades mediterrânicas: ix-xxvii, Lisboa: Fundação Calouste Gulbenkian.

DESCAMPS, Paul (1935), Le Portugal: la vie sociale actuelle, Paris: Firmin-Didot et Cie.

DIAS, Isabel (1998), “Exclusão Social e violência doméstica: que relação?”, in Sociologia: 189-205, Porto.

DIMEN, Muriel (1986), "Servants and Sentries:Women, Power and Social Reproduction in Kriovrisi”, in J. Dubisch (org.), Gender \& Power in Rural Greece: 53-67, Princeton, Nova Jersey: Princeton University Press.

DINÂMIA (1997), Caracterização Sociográfica das Mulheres Eleitas para as Autarquias Locais - 1993, Lisboa: STAPE: Ministério da Administração Interna.

DUBISCH, Jill (1986), “Introduction” in J. Dubisch (org.) Gender \& Power in Rural Greece: 4-41, Princeton, Nova Jersey: Princeton University Press.

DU BOULAY, Juliet (1974), Portrait of a Greek Mountain Village, Oxford: Clarendon Press.

DURKHEIM, Émile $\{1974$ (1895)\}, Las reglas del método sociológico, Madrid: Morata.

DURKHEIM, Émile $\{1977$ (1893)\}, A Divisão Social do Trabalho, Lisboa: Presença.

DURKHEIM, Émile (1983), Lições de Sociologia - A Moral, o Direito e o Estado, S. Paulo: T. A. Queiroz. ENGELS, Friedrich $\{1980$ (1884)\}, A Origem da Familia, da Propriedade Privada e do Estado, Lisboa: Editorial Presença. 
FERREIRA, Virgínia (1993), "Padrões de segregação das mulheres no emprego - Uma análise do caso português no quadro europeu", in B. S. Santos (org.) Portugal: Um retrato singular: 231-257, Porto: Afrontamento.

FERREIRA, Virgínia (1981), "Mulheres, família e trabalho doméstico no capitalismo", in Revista Crítica de Ciências Sociais, 6: 47-86.

FERREIRA, Virgínia (1999), “Os paradoxos da situação das mulheres em Portugal”, in Revista Crítica de Ciências Sociais, 52-53: 199-227.

FIRESTONE O. S. (1976), A Dialéctica do Sexo, Rio de Janeiro: Labor do Brasil.

FLANDRIN, Jean-Louis (1984), Familles. Parenté, maison, sexualité dans l'ancienne société, Paris: Éditions du Seuil.

FLANDRIN, Jean-Louis (1983), Un temps pour embrasser. Aux origines de la morale sexuelle occidentale (VI-XI siècles), Paris: Seuil.

FOUCAULT, Michel (1994), História da sexualidade. I. A vontade de saber, Lisboa: Relógio d'Água. FREUD, Sigmund \{1975 (1946)\}, Abrégé de psychanalyse, Paris: Presses Universitaires de France. GARNSEY, Elizabeth (1982), "Women's Work and Theories of Class and Stratification”, in A. Giddens e D. Held (orgs.), Classes, Power and Conflict, Londres: Macmillan Education.

GERALDES, Alice (1987), Gentes de minifúndio. Produção e reprodução social numa freguesia em mudança, Braga: Universidade do Minho (policopiado).

GOFFMAN, Erving (1974), Les Rites d'interaction, Paris: Minuit.

GONZALEZ, Juan Romero e ESPARCIA, Javier Perez (1992), Pobreza y desigualdad en los paises en desarrollo, Madrid: Editorial Síntesis.

GOODY, Jack (1983), The Development of the Family and Marriage in Europe.

HANDMAN, Marie Elisabeth (1992), « La structure de la famille, dévolution des biens et statut paradoxal des femmes en Grèce » in A. Almeida et al. (orgs.), Familles et contextes sociaux, Lisboa: Centro de Investigação e Estudos de Sociologia.

HAREVEN, Tamara K. (1982), Family Time \& Industrial Time, Cambridge: Cambridge University Press.

HARRIS, Olivia e YOUNG, Kate (1981), "Engendered Structures: Some Problems in the Analisys of Reproduction", in J. S. Khan e J. R. Llobera (orgs.), The Anthropology of Pre-Capitalist Societies: 109-147, Londres: MacMillan.

HARTMAN, Heidi (1982), "Capitalism, Patriarchy and Job Segregation by Sex”, in A. Giddens e D. Held (orgs.), Classes, Power and Conflict: 446-469, Londres: MacMillan Education Ltd.

HELLER, Agnes (1986), “The Sociology of everyday life”, in U. Himmelstrand (org.), The Social Reproduction and Culture: 150-163, Londres: Sage Publications.

HÉRITIER, Françoise (1989), “Masculino/feminino”, in Enciclopédia Einaudi, vol. 20, Parentesco, Lisboa: Imprensa Nacional-Casa da Moeda.

ITURRA, Raul \{1983 (1976)\} "Estratégias na organização doméstica da produção na Galiza rural”, in Ler História, 1: 81-109.

LEANDRO, Maria Engrácia (2001), Sociologia da Familia nas Sociedades Contemporâneas, Lisboa: Universidade Aberta.

LEVI-STRAUSS, Claude [1982 (1949)], As Estruturas Elementares do Parentesco, Lisboa: Vozes. 
LEVI-STRAUSS, Claude (1977), A Familia como Instituição, Porto: Rés.

LILJESTRÖM, Rita (1986), “Gender Systems and the Family”, in U. Himmelstrand (org.) Sociology: From Crisis to Science?, vol. II, The Social Reproduction of Organisation and Culture: 132-149, Londres: Sage Publications.

LUHMAN, Niklas $\{1982(1970)\}$, The Differentiation of Society, Nova Iorque: Columbia University Press.

MACHADO, Helena (1999), 'Vaca que anda no monte não tem boi certo': uma análise da prática judicial de normalização do comportamento sexual e procriativo da mulher", in Revista Crítica de Ciências Sociais, 55: 167-184.

MARCUSE, Herbert $\{1963$ (1955)\}, Eros et Civilisation, Paris: Éditions du Minuit.

MARCUSE, Herbert [1968(1964)], L'Homme unidimensionne: essai sur l'idéologie de la société industrielle avancée, Paris: Minuit.

MARQUES, Ana Paula (2002), Jovens Engenheiros: Entre o diploma e o emprego, Braga: Universidade do Minho.

MARX, Karl [1974 (1967)], o Capital, Lisboa: Delfos.

MARX, Karl e ENGELS, Friedrich [1976(1846)], A Ideologia Alemã , Lisboa: Presença.

MEAD, Herbert (1934), Mind, Self and Society: from the Standpoint of a Social Behaviorist, Chicago: University of Chicago Press.

MEDICK, Hans and SABEAN, David W. (1984) (orgs.), Interest and Emotion: Essays on the Study of Family and Kinship, Cambridge/ Paris: Cambridge University Press e Editions de la Maison des Sciences de l'Homme.

MEILLASSOUX, Claude (1977), Mulheres, Celeiros e Capitais, Porto: Afrontamento.

MENDES, José M. Oliveira (1997), “Mobilidade social em Portugal: o papel da diferença sexual e das quali- ficações", in Revista Crítica de Ciências Sociais, 49: 127-156.

MEPAT (Ministério de Equipamento, do Planeamento e da Administração do Território) (1998), Portugal - Uma visão estratégica para vencer o século XXI, Lisboa: Secretaria de Estado do Desenvolvimento Regional.

MÉNDEZ, Lourdes (1988), “Cousas de mulleres”. Campesinas, poder y vida cotidiana (Lugo 1940-1980), Barcelona: Anthropos.

MILLET, Kate (1974), Política Sexual, Lisboa: Publicações Dom Quixote.

NENCEL, Lorraine (1994), “The Secrets behind Sexual Desire:The Construction of Male Sexuality in Lima, Peru", in Etnofor, VII, 2: 59-75.

O’NEILL, Brian Juan (1984), Proprietários, Lavradores e Jornaleiras, Lisboa: Dom Quixote.

ORTNER \{1988 (1972)\}, Sexual Meanings: The Cultural Construction of Gender and Sexuality, Cambridge: Cambridge University Press.

PARSONS, Talcott (1956), "Family Structure and the Socialization of the Child", in T. Parsons e R. Bales (orgs.), Family, Socialization and Interaction Process: 35-131, Londres: Routledge \& Kegan Paul.

PERISTIANY, J. G. \{1988 (1965)\}, "Introdução" e "Honra e vergonha numa aldeia cipriota", in J. Peristiany (org.), Honra e Vergonha. Valores das sociedades mediterrâneas: 3-10, 139-155, Lisboa: Fundação Calouste Gulbenkian. 
PITT-RIVERS, Julian (1988), “Honra e posição social”, in J. G. Peristiany (org.), Honra e Vergonha. Valores das sociedades mediterrânicas: 11-61, Lisboa: Fundação Calouste Gulbenkian.

PITT-RIVERS, Julian $\{1997$ (1977)\}, Anthropologie de l'honneur, Paris: Hachette.

RAPP, Rayna (1983), "Peasants into Proletarians from the Household Out: An Analysis from the Inter-section of Anthropology and Social History”, in J. P. Menscher (org.), Social Anthropology of Peasantry: 32-47, Bombaim e Nova Iorque: Somaya Publications.

REICH, William \{1972 (1942)\}, La Psychologie de masses du fascisme, Paris: Payot.

REITER, Rayna (1975), “Men and Women in the South France: Public and Private Domains”, in R. Reiter (org.), Toward an Anthropology of Women: 252-282, Nova Iorque: Monthly Review Press.

RIBEIRO, Manuela e SACRAMENTO, Octávio (2002), "Prostituição feminina no espaço transfronteiriço ibérico - Um caso particular de circulação de pessoas”, in Cadernos do Noroeste, série Sociologia, Sociedade e Cultura, vol. 18 (1-2), 205-227.

RIEGELHAUPT, Joyce (1967), "Saloio Women: an Analysis of Informal and Formal Political and Economic Roles of Portuguese Peasant Women”, in Anthropological Quarterly, vol. 40, 3: 109-126.

ROBERTS, Richard (1984), “Women's Work and Women's Property: Household Social Relationship in the Maraka Textile Industry of the Nineteenth Century", in Comparative Studies in Society and History, vol. 26, 2: 229-250.

SANTO, Moisés Espírito (1980), Freguesia Rural ao Norte do Tejo, Lisboa: IED.

SANTOS, Boaventura de Sousa (1994), Pela Mão de Alice. O social e o político na pós-modernidade, Porto: Afrontamento.

SCHNEIDER, Jane (1971), "Of Vigilance and Virgins: Honor, Shame and Access to Resources in Mediterranean Societies", in Ethnology, vol. X, 1: 1-24.

SCOTT, James (1990), Domination and the Arts of Resistance: Hidden transcripts, New Haven e Londres: Yale University Press.

SEGALEN, Martine (1980), Mari et femme dans la société paysanne, Flammarion.

SEGALEN, Martine $\{1983$ (1980)], Love and Power in the Peasant Family. Rural France in the Nineteenth Century, Chicago: The University of Chicago Press.

SILVA, Manuel Carlos (1987), “Camponeses nortenhos: 'conservadorismo' ou estratégias de sobrevivência, mobilidade e resistência”, in Análise Social, 97: 407-445.

SILVA, Manuel Carlos (1991) “Casa e casas em espaço rural minhoto: o poder doméstico”, in Cadernos do Noroeste, vol. 4 (6-7): 79-99.

SILVA, Manuel Carlos (1998), Resistir e Adaptar-se. Constrangimentos e estratégias camponesas no Noroeste de Portugal, Porto: Afrontamento.

SILVA, Manuel Carlos (1998a), "Prostituição feminina: uma primeira abordagem para uma pesquisa”, in Cadernos do Noroeste, vol. 11, 1: 227-244.

SILVA, Manuel Carlos (1999), “A luta pela igualdade social: por uma articulação conceptual entre classe e género", in Fórum A Situação das Mulheres no Limiar do Século XXI, Lisboa: Editorial Avante.

SILVA, Manuel Carlos (2002), "Conflitos interfamiliares e 'mal de inveja”, in Análise Social, vol. XXXVII, 162: 209-241.

SILVA, Manuel Carlos e VAN TOOR, Marga (1988), "Camponeses e patronos: o caso de uma aldeia minhota", in Cadernos de Ciências Socais, 7: 51-80. 
SILVA, Manuel, MACHADO, Helena e SILVA, Susana (2002), "Direito, ciência e corpo feminino: a prosti- tuição como 'objecto de fronteira”', in Cadernos do Noroeste, série Sociologia, Sociedade e Cultura, vol. 18, 4: 183-203.

SOBRAL, José Manuel (1999), Trajectos: Passado e presente na vida de uma freguesia da Beira, Lisboa: Instituto de Ciências Sociais da Universidade de Lisboa.

TORRES, Anália C. (2001), Sociologia do Casamento. A Família e a questão feminina, Oeiras, Celta Editora.

VIEGAS; José Manuel Leite, FARIA, Sérgio (1999), As Mulheres na Política, Lisboa: Imprensa Nacional - Casa da Moeda.

VIEGAS; José Manuel Leite, FARIA, Sérgio (1999), “Participação política feminina. Percursos, constrangi- mentos e incentivos”, in Sociologia - Problemas e práticas, 30: 55-87.

WALL, Karin (1998), Famílias no Campo: Passado e presente em duas freguesias do Baixo Minho, Lisboa: Dom Quixote.

WALL, Karin e ALMEIDA, Ana Nunes (2001), "Família e quotidiano: Movimentos e sinais de mudança”, in J. M. Brandão de Brito (org.), o País e a Revolução: 277-307, Lisboa: Círculo de Leitores.

WALBY, S. (1997), Gender Transformations, Londres: Routledge.

WEBER, Max \{1978(1920)\}, Economy and Society, editado por G. Roth e C. Wittich, Berkeley e Londres: University of California Press.

WEEKS, J. (1986), Sexuality, Londres e Nova Iorque: Tavistock Publications.

WIARDA, Howard (1977), Corporatism and Development. The Portuguese Experience. Massachussetts: The University of Massachussetts Press.

WILLEMS, Emilio (1963), “On Portuguese Family Structure”, in K. Ishwaran (org.), International Studies in Sociological and Social Anthropology, vol. I, 65-79, Leiden: E. J. Brill.

ZARETSKY, E. (1973), Capitalism, The Family and Personal Life, Nova Iorque.

\section{NOTAS}

1. Assim, enquanto para uns autores a família, bem como a sua composição e eventual distribuição dos seus membros pelas diversas profissões, tarefas e demais actividades seriam moldadas por determinadas instituições e inelutáveis constrangimentos exógenos e endógenos (idade, género, classe, etnia), para outros assistiria às famílias e seus respectivos membros uma relativa capacidade e liberdade de tomar decisões, definir, seleccionar e implementar estratégias conducentes à obtenção de determinados objectivos. Para mais desenvolvimento a este respeito, cf. Silva (1991: 79 ss) e Leandro (2001: 51 ss).

2. A este respeito, urge uma investigação mais apurada, dado que, embora nos processos de separação, divórcio e tutela ou guarda dos filhos se reproduzam situações assimétricas em detrimento da mulher, há situações indiciadoras em que, face às dificuldades emergentes da "nova" relação mãe-filhos ou pai-filhos e respectivas redes de relações pós-divórcio, podem verificar-se casos manifestos ou latentes de subalternização não só feminina mas também masculina.

3. Cf. Dubisch (1986: 7, 24), Héritier (1989: 17ss), Amâncio (1993, 1994), Silva (1999). Como ilustrativo deste tipo de pensamento veja-se, por exemplo, a metáfora bíblica da formação da mulher a partir de uma costela do homem. Para maior desenvolvimento destas categorizações e 
representações binárias não só diferenciadas como assimetricamente construídas em base hierárquica e desigual, cf. nomeadamente Costa (1992: 119), Amâncio (1993: 130 ss), Silva, Machado e S. Silva (2002).

4. Esta questão prende-se com a discussão em torno do carácter patricêntrico/patriarcal ou matricêntrico/matriarcal das socie- dades tradicionais sobretudo agrárias. Em relação ao espaço luso-galaico, para além de legitimações de carácter biologista e retroprojecções ideológicas sem fundamento histórico, não há unanimidade entre os cientistas sociais. Alguns autores como Geraldes (1987: 469 ss) e Iturra (1983: 91 ss; 1988: 103 ss), aduzindo respectivamente a tónica androcêntrica nas prescrições legais e sobretudo nas práticas sociais designadamente o comportamento submisso, respeitoso e, por vezes, deferente da mulher face ao marido (tratandoo, por exemplo, por você ou senhor), têm salientado como traço dominante a autoridade masculina ou mesmo patriarcal em casas camponesas no Minho e na Galiza. Num pólo oposto, autores como Descamps (1935: 84, 191 ss, 273, 459 ss) e Willems (1963: 70 ss), com base em observações etnográficas de tipo monográfico e, por outro, mais recentemente, Santo (1980: 18, $78 \mathrm{ss}$ ), apelando a argumentos de tipo psicanalítico na variante do "incons- ciente colectivo" de Jung, reconhecem o poder patriarcal mas salientam ou sublimam a telúrica matricentralidade das relações sociais, em especial no Minho. Por fim, Cabral (1989: 109 ss), baseando-se em argumentos de tipo simbólico-valorativo e linguístico-cognitivo-interaccional (por exemplo, designação de "patroa" pelo marido), mantém sobre o poder conjugal uma problemática ambiguidade, posição partilhada também por Brettel (1991: 26), que, no quadro da análise da dinâmica dos movimentos demográficos e migratórios numa aldeia minhota, salienta ora a patricentralidade ora a matricentralidade dos grupos domésticos minhotos.

5. Também Lévi-Strauss (1977: 30 ss) destaca que a divisão sexual do trabalho, embora variável conforme os tempos e espaços societais, constitui um traço universal que contribui para explicar o casamento e suas diversas modalidades, o qual implica necessariamente, em maior ou menor extensão, como pré-requisito de qualquer organização social, a proibição de incesto entre parentes próximos e, consequentemente, a troca exogâmica de mulheres.

6. Cf., entre outros, Zaretsky 1973, Meillassoux 1977, Ferreira 1981: 48 ss, Wallerstein 1984, J. Brenner e B. Laslett 1986: 116 ss, Liljestrom 1986: 144. Esta ideia-força tem sido amplamente desenvolvida por diversos autores marxistas ao analisar a articulação entre diversos modos de produção no processo de acumulação e expansão do capitalismo.

7. Entre outros interditos, refira-se o não ter relações sexuais durante certos períodos (quaresma, festas tais como Natal e Páscoa), nem durante a gravidez, pois esta transgressão, contrariamente ao exemplar comportamento dos animais, representaria, segundo Santo Ambrósio e S. João Crisóstomo, a profanação do trabalho da criação divina nas entranhas da mulher (in Flandrin 1983: 84-85). E, quanto ao modo de relacionar-se sexualmente, era vedado fazê-lo pela retaguarda da mulher e impunha-se que as relações sexuais fossem feitas "com juízo" e sem paixão, tal como advertia S. Jerónimo: "O homem sábio deve amar a sua mulher com juízo, não com paixão. Que ele controle o ímpeto da voluptuosidade e não se deixe levar precipitadamente à cópula. Não há nada mais infame que amar uma esposa como uma amante... Adúltero é também o amoroso demasiado apaixonado pela sua mulher... Em relação à esposa doutrem, com efeito, todo o amor é vergonhoso; em relação à própria, o amor excessivo" (in Flandrin 1983: 116). Cf. também M. Almeida (2000: 75-81).

Segundo Flandrin (1983: 69 ss), estes interditos, para além da glorificação do celibato e da esterilidade por diversos pais-santos da Igreja Católica (Santo Agostinho, S. Gregório de Nisa, Santo Ambrósio, S. Jerónimo, S. Basílio, S. João Crisóstomo) poderiam, se rigorosamente observados, pôr em perigo o equilíbrio demográfico da Alta Idade Média, mesmo que os seus responsáveis não tivessem disso consciência.

8. Sem pretender de modo algum identificar Durkheim (1983) como inspirador de regimes corporativos totalizantes - é bem conhecido o seu empenho no sistema democrático vigente e a 
insistência nas fórmulas educativas pela persuasão e não pela repressão -, cabe, no entanto, referir que o corporativismo durkheimiano apresenta curiosas semelhanças com a doutrina social da Igreja, também esta perfilhada, em linha de princípio, por Salazar. No entanto, o corporativismo centralista inerente ao regime ditatorial salazarista afastou-o, em termos teóricopráticos, do corporativismo de associação idealisticamente pro- pugnado por alguns dissidentes internos do Estado Novo como, por exemplo, Castro Fernandes (in Wiarda 1977).

9. Com a emergência de doenças sexualmente transmissíveis (ontem doenças venéreas como a sífilis, hoje outras mortíferas como a sida), a premência de regulação e o controlo tornam-se ora razão ora pretexto cada vez mais imperativos em relação ao controlo das sexualidades alternativas ditas desviantes, “artificiais", “anormais" (v.g., uniões de facto, homossexualidades) e, em particular, com a sexualidade mercantilizada como seja a prostituição. Embora em moldes e latitudes diferentes e com meios mais sofisticados que no passado, a política sexual encontra-se também hoje e com maior acutilância no cerne das políticas de saúde pública, nomeadamente em torno do fenómeno da prostituição (cf. Silva 1998a; Machado 1999; Ribeiro e Sacramento 2002).

10. Alguns resultados obtidos da própria investigação em Aguiar, no concelho de Barcelos, mostram que, a par de 30,8\% de casos de dominação masculina e 37,5\% de relativo equilíbrio mais ou menos instável mas negociado, só em 8,6\% de casos era, de facto, a mulher quem comandava os destinos da casa (cf. Silva 1991: 87).

11. Para definir o poder doméstico importa ter presente, além do local de residência, a composição dos grupos domésticos e as interacções conjugais, o conceito de recursos materiais e simbólicos em termos amplos: bens patrimoniais, atributos estéticos e eróticos, experiência e força física, habilidades, saberes e qualificações, honra, prestígio e poder local, utilização do espaço e do tempo, entre outros.

12. Honra e vergonha são conceitos correlativos, ora numa perspectiva colectiva, ora numa abordagem individual. A honra e a honradez, não obstante serem vistas como atributos colectivos de certas sociedades nomeadamente mediterrânicas, necessitam de ser reactivadas e dependem da vontade dos membros da família e, em particular, do homem. o próprio conceito de honra pressupõe a posse não só de bens a defender como de atributos, valores e virtudes apreciadas num "verdadeiro homem", no "homem viril", adulto, geralmente casado, que se respeita e faz respeitar, se necessário pelo confronto físico, pela sua lealdade e equidade, pela sua generosidade e colaboração na comunidade, que se responsabiliza pelo sustento e pela protecção da família e se orgulha da sua reputação social e sucesso profissional. Já, porém, a mulher, para que seja considerada honrada, deve trabalhar e gerir bem a casa, tê-la limpa, cuidar do marido e dos filhos - os quais deverão andar bem asseados -, ser recatada e modesta, cumprir com as suas obrigações designadamente religiosas, comportar-se decentemente, de modo a não perder a honra, numa associação de conceitos sociomorais que obriga a estabelecer uma especial relação com a esfera sexual ("a pureza sexual") (cf. Pitt-Rivers 1988, 1997; Peristiany 1988).

13. Há contudo a referir uma considerável mudança desde os anos sessenta. Se bem que o contexto estrutural de há cerca de trinta anos era bem diferente, poder-se-á referir o crescente peso da população activa feminina, que em 1995 é de 41,4\% do total e em 2010 será de 45,5\% (MEPAT 1998: V-4).

14. Cf., a este respeito, Ferreira (1993: 239 ss), que distingue entre segregação sexual horizontal ou sectorial e segregação sexual vertical, a qual se prende com o nível de qualificações e com o baixo índice de emprego em lugares de enquadramento e chefia.

15. Em termos partidários, a sub-representação é diferenciada: maior no PSD ou PP e menor no PCP ou BE (Freire 1998: 116 ss). Acresce que, mesmo quando a mulher participa em órgãos do poder político, nomeadamente autárquico, são-lhe não raro atribuídos pelouros ou funções associadas à "acção social”, "educação e juventude", "cultura", contrariamente aos homens aos quais são conferidos os relativos a "obras e urbanismo", "desporto" (cf. Dinâmia 1997: 52), reproduzindo e prolongando ainda os tradicionais estereótipos em contexto doméstico. 
16. Um processo análogo ocorreu, por parte da tradicional teoria marxista, a respeito da definição das classes não pertencentes ao modo de produção capitalista, como por exemplo o campesinato. Aplicando a análise conceptual do esquema burguesia-proletariado ao campesinato, este é definido negativamente pelo que não é, em vez do que é positivamente pelas características específicas (cf. Silva 1987, 1998).

17. É esta razão androcêntrica que, por um lado, apresenta a sexualidade feminina como um perigoso elemento incontrolável, "diabólico", susceptível de "vitimizar" e "vulnerabilizar" o próprio homem e, por outro, apelando às metáforas da masculinidade em torno do sémen e dos órgãos genitais (v.g., "homem de colhões", "homem de tomates"), confere, com base nestes e noutros atributos fálicos, a superioridade ao homem (sobre seus directos concorrentes e) sobre a mulher.

18. Tal como o replicam, para a situação das camponesas em aldeias da Grécia, Handman (1992), Dimen (1986) e Dubisch (1986) e, para as camponesas em Lugo, na Galiza, Méndez (1988).

\section{RESUMOS}

Não obstante o relativo avanço, em termos legais e políticos, na defesa dos princípios de equidade de relações de género, recentes estudos a nível nacional e internacional confirmam as persistentes desigualdades de género em diversos contextos (ambientes laborais, interações quotidianas, valores e regulações simbólicas, enquadramentos institucionais).

Neste artigo, após uma revisão, em forma sintética e crítica, de alguns paradigmas teóricos que procuram explicar as desigualdades de género (concepções socio- biológicas, psicológicas, em especial psicanalíticas, estruturo-funcionalistas, marxista e weberianas), o autor propõe uma articulação entre os conceitos de género e classe. Tal implica a convergência do modelo marxista com o feminista e, indirectamente, um cruzamento frutífero entre o posicionamento (neo)marxista e weberiano, sendo este último articulável com a perspectiva interaccionista simbólica. Segue-se uma breve retrospectiva histórica e a correlativa desconstrução das formas essencialistas, reificadoras e legitimadores do statu quo.

Por fim, com uma breve ilustração sobre algumas desigualdades de género em Portugal, esboçase a hipótese de que, para além dos interesses inerentes aos mecanismos macro-económicos e institucionais de dominação, o controlo da força de trabalho feminina e os subsequentes fenómenos de segregação sócio-espacial e discriminação laboral reproduzem-se a diversos níveis: sócio-estrutural, organizacional e interaccional. A nível micro e meso, o poder da mulher varia em função de vários factores: recursos e recompensas, participação no processo produtivo, presença de uma hierarquia de papéis sexuais na divisão do trabalho, lugar ocupado na organização/instituição, lugar na reprodução da esfera familiar e nas interacções e negociações de papéis.

Despite the advance, in legal and political terms, of the defence of egalitarian principles within the rela- tion between men and women, recent (inter)national studies confirm the persisting social borders and inequalities of gender in many contexts (work, daily interactions, values and symbolic regulations, institutional frames).

In this paper, after a revisitation, in a synthetic and critical way, of some theoretical paradigms that look to explain these inequalities (v.g. socio-biological, psychological conceptions, the structural-functional, the Marxist model, the neo-Weberian) we propose an articulation between 
the concepts of gender and class. This implies a convergence of the Marxist model with the feminist one and, indirectly, a fruitful crossing between (neo)Marxism and Weberianism, being this one also articulated with symbolic interactionism. This is followed by a brief historical retrospective and correlative deconstruction of the essentialist, reifying and legitimating forms of the statu quo.

Finally, with a brief illustration of some of the gender inequalities in Portugal, we outline a hypothesis that states that, beyond the interests to the mechanisms of macro-economic and institutional domination, the control of the feminine labour force and subsequent phenomena of labour segregation and wage discrimination are whether reproduced or countered at different levels: socio-structural, organizational/institutional and interactive. At the micro and mesosocial levels, the power of the women differs in function of variable factors such as: available resources and rewards; participation in the productive process; presence of an hierarchical ranking of sexual roles in the division of labour; place occupied in the organization of the corporation or institution; place in the (re)productive sphere of the family unit; place in the interactions and negotiations of roles.

En dépit de l'avance, en termes légaux et politiques, de la défense des principes d'équité de relations de genres, de récentes études nationales et internationales confirment les inégalités persistantes de ce type dans des contextes divers (travail, interactions quotidiennes, valeurs et régulations symboliques, encadrements institutionnels).

Dans cet article, après révision, d'une manière synthétique et critique, de quelques paradigmes théoriques qui cherchent à expliquer les inégalités de genres (conceptions sociobiologiques, psychologiques, plus spécialement psychanalytiques, structurofonctionnalistes, marxistes et neoweberiennes), l'auteur pro- pose une articulation entre les concepts de genre et de classe. Ceci implique une convergence du modèle marxiste avec le féministe et, indirectement, un croisement fructueux entre la position (néo)marxiste et weberienne, étant cette dernière articulable avec la perspective interactionniste symbolique. Ceci est suivi d'une courte rétrospective historique et déconstruction corrélative des formes essentialistes, reificatrices et légitimatrices du statu quo. Finalement, avec une brève illustration de certaines des inégalités de genre au Portugal, l'auteur décrit une hypothèse qui affirme que, au delà des intérêts inhérents aux mécanismes macroéconomiques et institutionnels de domination, le contrôle de la force de travail féminine et les phénomènes ultérieurs de ségrégation socio-spatiale et de discrimination de travail se reproduisent a des niveaux divers : sociostructurel, organisationnel et interactionnel. Au niveau micro et meso, le pouvoir de la femme diffère en fonction de plusieurs facteurs: ressources et récompenses, participation au processus productif, présence d'un rang hiérarchique des rôles sexuels dans la division du travail, place occupée dans l'organisation/ institution, place dans la reproduction de la sphère familiale et des interactions et négociations de rôles.

\section{ÍNDICE}

Palavras-chave: desigualdade e discriminação, género e classe, feminismo e marxismo, controlo da mulher, poder feminino e emancipação

\section{AUTOR}

\section{MANUEL CARLOS SILVA}

Departamento de Sociologia 
Universidade do Minho mcsilva@ics.uminho.pt 